\title{
CXCR5 wt Allele
}

National Cancer Institute

\section{Source}

National Cancer Institute. CXCR5 wt Allele. NCI Thesaurus. Code C51315.

Human CXCR5 wild-type allele is located in the vicinity of $11 \mathrm{q} 23.3$ and is approximately 12 $\mathrm{kb}$ in length. This allele, which encodes C-X-C chemokine receptor type 5 protein, plays a role in B cell migration and localization within specific anatomic locations. 